\title{
Antimycobacterial and PknB Inhibitory Activities of Venezuelan Medicinal Plants
}

\author{
C. A. Aranaga $\left(\mathbb{D},{ }^{1,2}\right.$ S. Fraile, ${ }^{3}$ A. Torres, ${ }^{2}$ A. Falco, ${ }^{2,4}$ F. Michelangeli, ${ }^{3}$ and H. Takiff ${ }^{2,5}$ \\ ${ }^{1}$ Grupo de Investigación en Química y Biotecnología, Facultad de Ciencias Básicas, Universidad Santiago de Cali, Cali, Colombia \\ ${ }^{2}$ Laboratorio de Genética Molecular, Instituto Venezolano de Investigaciones Científicas, Caracas, Venezuela \\ ${ }^{3}$ Centro de Biofísica y Bioquímica, Instituto Venezolano de Investigaciones Científicas, Caracas, Venezuela \\ ${ }^{4}$ Grupo de Investigación en Microbiología Industria y Ambiente, Universidad Santiago de Cali, Cali, Colombia \\ ${ }^{5}$ Integrated Mycobacterial Pathogenomics, Institut Pasteur, Paris, France \\ Correspondence should be addressed to C. A. Aranaga; carlos.aranaga00@usc.edu.co
}

Received 29 May 2020; Accepted 17 July 2020; Published 1 August 2020

Academic Editor: Giuseppe Comi

Copyright $\odot 2020$ C. A. Aranaga et al. This is an open access article distributed under the Creative Commons Attribution License, which permits unrestricted use, distribution, and reproduction in any medium, provided the original work is properly cited.

Global control and elimination of tuberculosis are hindered by the high prevalence of drug-resistant strains, making the development of new drugs to fight tuberculosis a public health priority. In this study, we evaluated 118 extracts from 58 Venezuelan plant species for their ability to inhibit the growth of Mycobacterium tuberculosis mc $^{2} 6020$, using the agar dilution method. Additionally, we determined the ability of these extracts to inhibit the activity of PknB protein, an essential M. tuberculosis serine/ threonine kinase, using a high-throughput luminescent assay. Of the 118 extracts tested, 14 inhibited bacterial growth with a minimum inhibitory concentration $\leq 500 \mu \mathrm{g} / \mathrm{ml}$, and 36 inhibited the kinase activity with a half-maximal inhibitory concentration $<200 \mu \mathrm{g} / \mathrm{ml}$. Five extracts inhibited M. tuberculosis growth and inhibited the activity of the kinase protein, suggesting that this could be the basis of their growth inhibition.

\section{Introduction}

According to the data from the World Health Organization (WHO), 10 million people developed tuberculosis (TB) in 2018, while 1.5 million died from this disease [1]. In 2014, the WHO launched the "END TB," strategy, which seeks to end the global tuberculosis epidemic. One of the pillars of this strategy is the search for new treatment alternatives for both drug-sensitive and multidrug-resistant tuberculosis strains.

Just three new compounds, bedaquiline, delamanid, and pretomanid, have received approval for use against TB $[2,3]$. Although they appear to have good anti-TB activity and could be useful for treating strains resistant to other agents, their potential for side effects and the possible emergence of resistant strains $[4,5]$ have led to caution and reservations about their appropriate role in treatment regimens. Therefore, the search for new drugs that are safe and effective in the control of TB continues to be a priority.
Recent studies have shown the potential of natural extracts as the basis for new drugs [6,7]. Microorganisms and plants have exceptional chemical and structural diversity and represent a valuable source of biologically active molecules with potential as new antimicrobials [8]. For example, ursolic acid and hydroquinone, isolated from methanolic extracts of Artemisia capillaris, inhibit the growth of susceptible and resistant strains of $M$. tuberculosis and have promise as potential chemotherapeutic agents [9]. Ethnopharmacological research helps to focus screening efforts by identifying groups of plants that are used in traditional medicine to treat infectious diseases. Screening performed with extracts of medicinal plants used in India, Mexico, and South Africa [10-12] demonstrated that some of these extracts have high activity for inhibiting the growth of $M$. tuberculosis and other mycobacteria.

In Venezuela, many indigenous and local communities continue to use plants for medicinal purposes, but few of 
these plants have been evaluated for their antituberculosis activity. We were particularly interested in extracts that inhibited the activity of $\mathrm{PknB}$, a serine/threonine kinase that appears to be essential in Mycobacteria. However, compounds found to inhibit enzyme activity with in vitro screens can, for a variety of reasons, fail to inhibit the growth of the whole bacteria. Therefore, in this study, we selected 118 extracts from 58 plant species used in traditional Venezuelan medicine and tested their ability to inhibit the in vitro activity of the $M$. tuberculosis serine/ threonine-protein kinase $\mathrm{PknB}$ and also their ability to inhibit the growth of M. tuberculosis $\mathrm{mc}^{2} 6020$.

\section{Materials and Methods}

2.1. Plant Material. The extracts tested were obtained from plants in the botanical species collection (MedPlant) [13] of the Gastrointestinal Physiology Laboratory of Instituto Venezolano de Investigaciones Científicas (IVIC), which is covered by an "Access Contract to Genetic Resources" signed between IVIC and the Ministry of Environment and Natural Resources.

A total of 118 ethanolic extracts were obtained from 58 plant species, belonging to 45 genera and 33 families (see Table S1 in the Supplementary Material). The plants were collected in the Venezuelan states of Amazonas, Bolívar, Cojedes, Mérida, Miranda, and Monagas, as shown in Figure 1. The extracts include different plant organs, such as bark, branch, flower, fruit, and leaf. Plants were selected according to their ethnopharmacological activity for the treatment of symptoms associated with lung diseases (cough, fever, nasal congestion, and asthma) from the PlantMed database, which contains data on Venezuelan and neotropical plants reported as having medicinal use.

The plant materials were dried at room temperature. After grinding in a blender, plant material was macerated in three volumes of $95 \%$ ethanol for at least 3 days. The material was filtered, and the alcoholic extract was concentrated and dried by a rotary evaporator and lyophilization. Stock extract solutions $(100 \mathrm{mg} / \mathrm{ml})$ were prepared in $100 \%$ dimethyl sulfoxide (DMSO) immediately before use.

2.2. Strain and Growth Conditions. M. tuberculosis $\mathrm{mc}^{2} 6020$ was grown in $7 \mathrm{H} 9$ and $7 \mathrm{H} 11$ Middlebrook media to which was added $10 \%$ ADC $(0.5 \%$ bovine serum albumin, $0.2 \%$ glucose, and $0.85 \% \mathrm{NaCl})$, L-lysine $(40 \mu \mathrm{g} / \mathrm{ml})$, and pantothenic acid $(20 \mu \mathrm{g} / \mathrm{ml})$. The $7 \mathrm{H} 9$ medium additionally contained Tween-80 (0.5\% v/v) and glycerol (0.2\% v/v) [14]. The strain was incubated at $37^{\circ} \mathrm{C}$ in an incubator-shaker until reaching an optical density at $600 \mathrm{~nm}\left(\mathrm{OD}_{600 \mathrm{mn}}\right)$ of 0.6 (approximately $3 \times 10^{8} \mathrm{CFU} / \mathrm{ml}$ ) and then diluted in a $1: 2,000$ ratio for studies of growth inhibition. Cultures of Escherichia coli BL21 (DE3 pLys) were cultured at $37^{\circ} \mathrm{C}$ in LB broth in an incubator-shaker until reaching an $\mathrm{OD}_{600 \mathrm{~nm}}$ of 0.6.

2.3. Antituberculosis Screening. The antituberculosis activity of the extracts was determined using the agar dilution method. For this, $35 \times 10 \mathrm{~mm}$ Petri dishes were prepared with medium supplemented with a plant extract at a final concentration of $500 \mu \mathrm{g} / \mathrm{ml}$. Petri dishes with $0.5 \%$ DMSO but without extracts were prepared as growth controls, while as a positive control, plates supplemented with Kanamycin $(25 \mathrm{mg} / \mathrm{ml})$ were used. M. tuberculosis $\mathrm{mc}^{2} 6020$ cultures $(10 \mu \mathrm{l})$ were spread onto the medium, and then, the Petri dishes were incubated at $37^{\circ} \mathrm{C}$ for 25 to 30 days, or until growth was observed in the control without extract. The extract containing plates on which no growth was seen was taken to indicate growth inhibition, and the minimum inhibitory concentration (MIC) was established by repeating the above procedure with medium containing $100,200,300,400$, and $500 \mu \mathrm{g} / \mathrm{ml}$.

2.4. Recombinant Protein Expression and Purification. The 279-residue kinase domain of PknB (DQPknB) [15] and fulllength GarA [16], natural substrates for the PknB protein, were expressed in Escherichia coli BL21 (DE3 pLys). Cultures were grown until an $\mathrm{OD}_{600 \mathrm{~nm}}$ of 0.6 and induced by the addition of IPTG (final conc. $1 \mathrm{mM}$ ), incubated at $37^{\circ} \mathrm{C}$ for an additional eight hours and then centrifuged at 1,503 g. The pellet was resuspended in lysis buffer $(50 \mathrm{mM}$ of Tris- $\mathrm{HCl}$, $500 \mathrm{mM}$ of $\mathrm{NaCl}$, and $20 \mathrm{mM}$ of imidazole, at a $\mathrm{pH}$ of 7.5) in the presence of lysozyme and DNase I from bovine pancreas (Sigma, St Louis, MO, USA). The bacteria were sonicated, and the resulting lysate was centrifuged at $18,407 \mathrm{~g}$ for $15 \mathrm{~min}$. The supernatant was passed through a $0.45 \mu \mathrm{m}$ syringe filter and then loaded onto a Ni Sepharose ${ }^{\mathrm{TM}}$ high-performance column (Amersham) using a fast protein liquid chromatography (FPLC) system. The elution was performed with an imidazole gradient $(0.0-0.5 \mathrm{M})$, and the fractions containing the protein of interest were visualized by sodium dodecyl sulfate-polyacrylamide gel electrophoresis (SDS-PAGE).

2.5. Phosphorylation Test. Phosphorylation assays were carried out using the commercial Kinase Glo kit (Promega) in a final volume of $100 \mu \mathrm{l}$ in 96-well solid white polystyrene microplates. The concentrations of ATP $(10 \mu \mathrm{M})$, DQPknB $(0.056 \mu \mathrm{M})$, and $\operatorname{GarA}(0.48 \mu \mathrm{M})$ were standardized using the manufacturer's recommendations. All reactions were carried out at room temperature and were started with reaction buffer mixture $\left(200 \mathrm{mM}\right.$ of Tris, $8 \mathrm{mM}$ of $\mathrm{MnCl}_{2}, 10 \mathrm{mM}$ of $\mathrm{KF}$, and $1 \mathrm{mM}$ of DTT), GarA, DQPknB, and the extract (10, $30,65,125,250$, and $500 \mu \mathrm{g} / \mathrm{ml})$. A negative control was elaborated by replacing the volume of the extract with DMSO. After $10 \mathrm{~min}$, ATP was added, and the reaction was incubated for an additional $10 \mathrm{~min}$. At the end of this period, the reaction was stopped by the addition of $50 \mu \mathrm{l}$ of the Kinase Glo reagent, and after another $10 \mathrm{~min}$, the luminescent signal was measured on a SpectraMax Gemini XS microplate spectrofluorometer (Molecular Devices). Halfmaximal inhibitory concentration $\left(\mathrm{IC}_{50}\right)$ values were calculated using the GraphPad Prism 5 software.

\section{Results}

We evaluated the inhibitory activity of 118 extracts of Venezuelan medicinal plants on the in vitro activity of the $\mathrm{PknB}$ protein and on the growth of the $M$. tuberculosis 


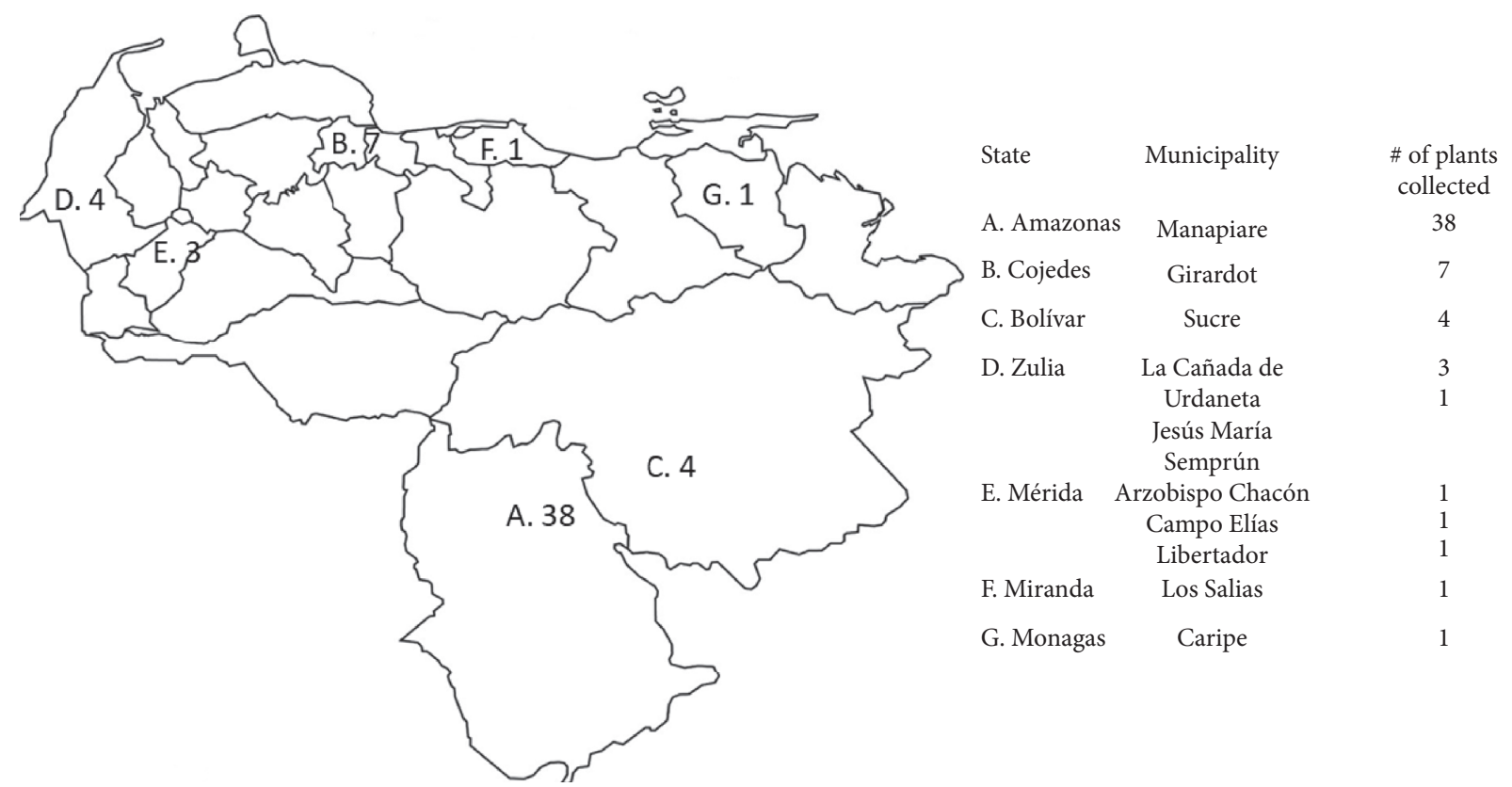

Figure 1: Plant collection sites. The plants were collected in 7 states of Venezuela, the main collection site being the Amazon state.

$\mathrm{mc}^{2} 6020$. The results obtained show that 14 extracts $(11.76 \%)$ inhibited the growth of the bacteria at a concentration $\leq 500 \mu \mathrm{g} / \mathrm{ml}$ (Table 1$)$.

The leaf extract of the species Piper sanvicentense exhibited the best activity against the growth of $M$. tuberculosis $\mathrm{mc}^{2} 6020$ with an MIC of $100 \mu \mathrm{g} / \mathrm{ml}$, followed by the inner bark of Eschweilera parvifolia with an MIC of $300 \mu \mathrm{g} /$ $\mathrm{ml}$ and extracts of inner bark and branch of Protium heptaphyllum with an MIC of $400 \mu \mathrm{g} / \mathrm{ml}$. All other growth inhibiting extracts (Piper marginatum (stem), Macoubea guianensis (leaf), Senna silvestris (flower), Bromelia goeldiana (fruit), Polypodium aureum (stem), Byrsonima crassifolia (flower), Hyptis dilatata (flower and root), Xylopia aromatica (leaf), and Curatella americana (leaf)) showed MICs of $500 \mu \mathrm{g} / \mathrm{ml}$.

Of the 36 extracts capable of inhibiting the in vitro activity of DQPknB, four had an $\mathrm{IC}_{50}$ lower than $50 \mu \mathrm{g} / \mathrm{ml}$, while 19 had an $\mathrm{IC}_{50}$ between 50 and $100 \mu \mathrm{g} / \mathrm{ml}$ and the remaining 13 exhibited an $\mathrm{IC}_{50}$ between 100 and $200 \mu \mathrm{g} / \mathrm{ml}$ (Table 2).

Six extracts $(5.04 \%)$ were found to inhibit both the in vitro activity of $\mathrm{PknB}$ and the growth of $M$. tuberculosis $\mathrm{mc}^{2} 6020$ (3), the inner bark of Eschweilera parvifolia and Protium heptaphyllum, the branch of Protium heptaphyllum, the flower of Byrsonima crassifolia, and the young leaves of Curatella americana and Xylopia aromatica.

\section{Discussion}

In this study, we selected 58 species of Venezuelan medicinal plants used by indigenous communities for the treatment of respiratory symptoms and evaluated extracts of different plant parts in a screen for natural compounds that have potential as antituberculosis. We tested a total of 118 extracts of different plant parts and of the 14 that inhibited the growth of $M$. tuberculosis $\mathrm{mc}^{2} 6020$ and 36 that inhibited the in vitro activity of PSTK PknB, and there were five that had both inhibitory activities.

The plants that showed activity against growth were P. sanvicentense (Piperaceae), E. parvifolia (Lecythidaceae), Pro. heptaphyllum (Burseraceae), Brom. goeldiana (Bromeliaceae), B. crassifolia (Malpighiaceae), C. americana (Dilleniaceae), H. dilatata (Lamiaceae), M. guianensis (Apocynaceae), P. marginatum (Piperaceae), Pol. aureum (Polypodiaceae), S. silvestris (Caesalpiniaceae), and $X$. aromatica (Annonaceae).

Our finding that an ethanolic extract bark of $C$. americana inhibited $M$. tuberculosis growth with an MIC of $500 \mu \mathrm{g} / \mathrm{ml}$ agreed with the results of Pavan et al. [17], who found that a methanolic extract of the bark inhibited the growth of M. tuberculosis H37Rv with the same MIC (Table 1), thus confirming the presence of compounds with antituberculosis activity in this species. We also tested extracts of young leaves, leaves, flowers, and branches of C. Americana, but these had MICs that were higher than $500 \mu \mathrm{g} / \mathrm{ml}$ (data not shown), suggesting a differential distribution of the active metabolites throughout the plant. All C. americana extracts also showed activity against $\mathrm{DQPknB}$, with an $\mathrm{IC}_{50}$ lower than $200 \mu \mathrm{g} / \mathrm{ml}$. However, while the lowest MIC for growth inhibition was in the bark extract, the extract with the lowest $\mathrm{IC}_{50}$ for inhibiting $\mathrm{PknB}$ activity was from young leaves, with an $\mathrm{IC}_{50}$ of $39.5 \mu \mathrm{g} / \mathrm{ml}$, while that of the bark was $124.9 \mu \mathrm{g} / \mathrm{ml}$.

Similarly, the plant parts of $H$. dilatata and E. parvifolia whose extracts had the greatest capacity to inhibit kinase activity were not the parts of these plants that were best at inhibiting bacterial growth (Tables 1 and 2). This could suggest that the molecules that inhibit kinase activity are different from those that mediate growth inhibition. 
Table 1: Antimycobacterial activity of plant extracts against $M$. tuberculosis $\mathrm{mc}^{2} 6020$.

\begin{tabular}{lcc}
\hline Botanical species (family) & Voucher/collection number & Part \\
\hline Piper sanvicentense (Piperaceae) & $25263 \mathrm{AF}$ & Leaf \\
Eschweilera parvifolia (Lecythidaceae) & $01441 \mathrm{BM}$ & Inner bark \\
Protium heptaphyllum (Burseraceae) & $16278 \mathrm{AF} / \mathrm{ml})$ \\
Protium heptaphyllum (Burseraceae) & $16278 \mathrm{AF}$ & Inner bark \\
Bromelia goeldiana (Bromeliaceae) & $01488 \mathrm{BM}$ & Branch \\
Byrsonima crassifolia (Malpighiaceae) & $00485 \mathrm{BM}$ & Fruit \\
Curatella americana (Dilleniaceae) & $01891 \mathrm{BM}$ & Flower \\
Hyptis dilatata (Lamiaceae) & $01036 \mathrm{BM}$ & Bark \\
Hyptis dilatata (Lamiaceae) & $00507 \mathrm{BM}$ & Flower \\
Macoubea guianensis (Apocynaceae) & $00582 \mathrm{BM}$ & Root \\
Piper marginatum (Piperaceae) & $00485 \mathrm{BM}$ & Leaf \\
Polypodium aureum (Polypodiaceae) & $00834 \mathrm{BM}$ & Stem \\
Senna silvestris (Caesalpiniaceae) & $00507 \mathrm{BM}$ & Stem \\
Xylopia aromatica (Annonaceae) & $14612 \mathrm{AF}$ & Flower \\
\hline
\end{tabular}

TABLE 2: The activity of plant extracts against DQPknB of M. tuberculosis.

\begin{tabular}{|c|c|c|c|}
\hline Botanical species (family) & Voucher/collection number & Part & $\mathrm{IC}_{50}(\mu \mathrm{g} / \mathrm{ml})$ \\
\hline Byrsonima crassifolia (Malpighiaceae) & $00485 \mathrm{BM}$ & Flower & 30.4 \\
\hline Protium heptaphyllum (Burseraceae) & $16278 \mathrm{AF}$ & Internal bark (root) & 37.4 \\
\hline Senna silvestris (Caesalpiniaceae) & $00507 \mathrm{BM}$ & Leaf & 37.4 \\
\hline Curatella americana (Dilleniaceae) & $01053 \mathrm{BM}$ & Young leaf & 39.5 \\
\hline Cochlospermum orinocense (Bixaceae) & $01473 \mathrm{BM}$ & Stem & 55 \\
\hline Eschweilera parvifolia (Lecythidaceae) & $01441 \mathrm{BM}$ & Branch & 58.8 \\
\hline Vismia guianensis (Clusiaceae) & $01523 \mathrm{BM}$ & Leaf & 58.8 \\
\hline Waltheria indica (Sterculiaceae) & $16607 \mathrm{AF}$ & Whole plant without root & 59.1 \\
\hline Vochysia ferruginea (Vochysiaceae) & $01286 \mathrm{BM}$ & Stem & 59.5 \\
\hline Oenocarpus bataua (Arecaceae) & $01524 \mathrm{BM}$ & Root & 60.9 \\
\hline Humiria balsamífera (Humiriaceae) & $00189 \mathrm{BM}$ & Leaf & 64.7 \\
\hline Protium heptaphyllum (Burseraceae) & $16278 \mathrm{AF}$ & Branch & 66 \\
\hline Hyptis dilatata (Lamiaceae) & $00507 \mathrm{BM}$ & Root & 66.6 \\
\hline Uncaria guianensis (Rubiaceae) & $01525 \mathrm{BM}$ & Bark & 71.2 \\
\hline Vismia guianensis (Clusiaceae) & $01523 \mathrm{BM}$ & Bark & 75.2 \\
\hline Eschweilera parvifolia (Lecythidaceae) & $01441 \mathrm{BM}$ & Internal bark (root) & 76.5 \\
\hline Euterpe precatoria (Arecaceae) & $01690 \mathrm{BM}$ & Root & 77.4 \\
\hline Warscewiczia coccinea (Rubiaceae) & $01316 \mathrm{BM}$ & Stem & 79 \\
\hline Protium crassipetalum (Burseraceae) & $01409 \mathrm{BM}$ & Bark & 79.7 \\
\hline Curatella americana (Dilleniaceae) & $01053 \mathrm{BM}$ & Flower & 81.9 \\
\hline Hyptis dilatata (Lamiaceae) & $00507 \mathrm{BM}$ & Leaf, branch without flower & 81.9 \\
\hline Xylopia aromatica (Annonaceae) & $14612 \mathrm{AF}$ & Young leaf & 93.6 \\
\hline Protium heptaphyllum (Burseraceae) & $16278 \mathrm{AF}$ & Leaf & 95.7 \\
\hline Croton cuneatus (Euphorbiaceae) & $01247 \mathrm{BM}$ & Young leaf & 124.9 \\
\hline Curatella americana (Dilleniaceae) & $01053 \mathrm{BM}$ & Bark & 124.9 \\
\hline Vochysia ferrugínea (Vochysiaceae) & $01286 \mathrm{BM}$ & Leaf & 130.9 \\
\hline Byrsonima crassifolia (Malpighiaceae) & $00485 \mathrm{BM}$ & Internal bark (root) & 144 \\
\hline Cochlospermum orinocense (Bixaceae) & $01473 \mathrm{BM}$ & Flower & 144.2 \\
\hline Curatella americana (Dilleniaceae) & $01053 \mathrm{BM}$ & Leaf & 146 \\
\hline Cochlospermum orinocense (Bixaceae) & $01473 \mathrm{BM}$ & Leaf & 156.9 \\
\hline Parkia pendula (Mimosaceae) & $00414 \mathrm{BM}$ & Bark & 158.3 \\
\hline Croton cuneatus (Euphorbiaceae) & $01250 \mathrm{BM}$ & Internal bark (root) & 161.7 \\
\hline Tapirira guianensis (Anacardiaceae) & $14733 \mathrm{AF}$ & Flower & 164.4 \\
\hline Jacaranda copaia (Bignoniaceae) & $22150 \mathrm{AF}$ & Young leaf & 174.1 \\
\hline Eschweilera parvifolia (Lecythidaceae) & $01441 \mathrm{BM}$ & Leaf & 183.3 \\
\hline Vismia cayennensis (Clusiaceae) & $01484 \mathrm{BM}$ & Leaf & 185.8 \\
\hline
\end{tabular}

Another possibility is that molecules that inhibit kinase activity in vitro have trouble penetrating the bacterial cell wall to inhibit the enzyme in live bacteria. Nevertheless, our study shows that C. americana, H. dilatata, and E. parvifolia are promising species for molecules with antituberculosis potential. 
TABLE 3: Extracts that showed activity against DQPknB and $M$. tuberculosis $\mathrm{mc}^{2} 6020$.

\begin{tabular}{lccc}
\hline Botanical species & Part & IC $_{50}$ & CMI \\
\hline Eschweilera parvifolia & Internal bark (root) & 76.53 & 300 \\
Protium heptaphyllum & Internal bark (root) & 37.40 & 400 \\
Protium heptaphyllum & Branch & 66.05 & 400 \\
Byrsonima crassifolia & Flower & 30.41 & 500 \\
Curatella americana & Young leaf & 146.04 & 500 \\
Xylopia aromatica & Young leaf & 93.63 & 500 \\
\hline
\end{tabular}

The stem extract from $P$. marginatum inhibited $M$. tuberculosis growth with an MIC of $500 \mu \mathrm{g} / \mathrm{ml}$. Ethanolic extracts of $P$. marginatum have been previously shown to inhibit the growth of Porphyromonas gingivalis ATCC 33277, Fusobacterium nucleatum ATCC 25586, and Prevotella intermedia ATCC 25611 [18]. P. marginatum essential leaf oil showed a bactericidal effect against Xanthomonas albilineans and $X$. campestris pv. campestris and a fungistatic effect against Alternaria solani [19]. Terpenoid compounds have shown to have moderate to high activity against $M$. tuberculosis, and the presence of these compounds in P. marginatum could explain their antituberculosis and antimicrobial activity [18].

Previous research established the potential of the ethanolic extract of $P$. sanvicentense against breast cancer MDAMB-231, prostate cancer PC-3, and human colon cancer HT29 cell lines [13], but this is the first report of its antibacterial activity. Of the 118 extracts we tested, the $P$. sanvicentense extract had lowest MIC for inhibiting $M$. tuberculosis growth $(100 \mu \mathrm{g} / \mathrm{ml})$. Although it did not show any ability to inhibit kinase activity, $P$. sanvicentense could be a promising candidate for chemical analysis. This is also the first report of antibacterial activity in the species Brom. goeldiana, M. guianensis, and Pol. aureum, whose fruit, leaf, and stem extracts, respectively, showed activity only against bacterial growth at an MIC of $500 \mu \mathrm{g} / \mathrm{ml}$.

Although antibacterial activity has previously been described in B. crassifolia, Pro. heptaphyllum, and Xylopia aromatica [20-24], we found that only some of the plant part extracts inhibited both $M$. tuberculosis growth and the kinase activity. The flower extract of $B$. crassifolia had an $\mathrm{IC}_{50}$ of $30.4 \mu \mathrm{g} / \mathrm{ml}$ and an MIC of $500 \mu \mathrm{g} / \mathrm{ml}$, while the inner bark extract showed an $\mathrm{IC}_{50}$ of $144 \mu \mathrm{g} / \mathrm{ml}$ but an MIC higher than $500 \mu \mathrm{g} / \mathrm{ml}$. Similarly, an extract of the inner bark of Pro. heptaphyllum had an $\mathrm{IC}_{50}$ of $37.4 \mu \mathrm{g} / \mathrm{ml}$ and an MIC of $400 \mu \mathrm{g} / \mathrm{ml}$, but the leaf extract had an $\mathrm{IC}_{50}$ of $95.7 \mu \mathrm{g} / \mathrm{ml}$ and an MIC over $500 \mu \mathrm{g} / \mathrm{ml}$. The young leaf extract of Xylopia aromatica inhibited both growth and kinase activity $\left(\mathrm{MIC}=500 \mu \mathrm{g} / \mathrm{ml}\right.$ and $\left.\mathrm{IC}_{50}=93.6 \mu \mathrm{g} / \mathrm{ml}\right)$, while the other extracts of this plant showed neither activity. Terpenoid compounds have been shown to possess high antituberculosis activity [25]. Phytochemical studies of the essential oils of X. aromatica and Prot. heptaphyllum leaves demonstrated the presence of various terpenes, including spathulenol $[20,21]$. This sesquiterpene has been shown to have antibacterial activity against Cryptococcus neoformans, Enterococcus faecalis, and Staphylococcus aureus [26].
The extracts of Jacaranda copaia, Oenocarpus bataua, Parkia pendula, Protium crassipetalum, Tapirira guianensis, Uncaria guianensis, Vismia cayennensis, Vismia guianensis, Vochysia ferrugínea, Waltheria indica, and Warscewiczia coccinea inhibited the kinase, but not mycobacterial growth. Nevertheless, identification of the kinase inhibiting metabolites could provide new lead compounds for the design of new drugs.

The search for new antituberculosis drugs continues to be a challenge, but the high incidence of this disease makes it an important priority. In this study, we documented the antimycobacterial potential of some Venezuelan plants for which antibacterial activity has not been previously reported and demonstrated the importance of ethnopharmacological knowledge in the search for botanical sources with biological activity. To our knowledge, this is the first study demonstrating the in vitro activity of natural extracts on the activity of the catalytic domain of the M. tuberculosis protein PknB. Serine/threonine kinases are important targets for anticancer agents [27] and have been proposed as targets for antituberculosis drugs. PknB is essential for M. tuberculosis [28], but no drug targeting it has yet been identified. In the extracts, we identified that plant extracts inhibit both $M$. tuberculosis growth and the kinase, and it is tempting to believe the same molecules contain both inhibitory activities, but this must be proven when the active compounds are successfully isolated and identified.

\section{Conclusions}

P. sanvicentense (Piperaceae), E. parvifolia (Lecythidaceae), Pro. heptaphyllum (Burseraceae), Brom. goeldiana (Bromeliaceae), B. crassifolia (Malpighiaceae), C. americana (Dilleniaceae), H. dilatata (Lamiaceae), M. guianensis (Apocynaceae), P. marginatum (Piperaceae), Pol. aureum (Polypodiaceae), S. silvestris (Caesalpiniaceae), and X. aromatica (Annonaceae) total ethanol extracts presented outstanding antimicrobial activity against $M$. tuberculosis $\mathrm{mc}^{2} 6020$

Of the 36 extracts that were shown to inhibit the activity of the PknB protein, only 5 were able to inhibit the growth of M. tuberculosis. Further studies should be performed to determine whether compounds that inhibit the activity of protein kinase also affect bacterial growth.

\section{Data Availability}

The data used to support the findings of this study are included within the article and are available from the corresponding author upon request.

\section{Conflicts of Interest}

The authors have declared that there are no conflicts of interest.

\section{Acknowledgments}

The authors would like to express gratitude to Dr. Pedro Alzari (Pasteur Institute, France), for providing the plasmids 
for the overexpression of DQPknB and GarA. This work was supported by the Ley Orgánica de Ciencia, Tecnología e Innovación LOCTI-Venezuela (grant: Nuevos Fármacos Contra la Tuberculosis) and the Universidad Santiago de Cali (DGI project no. 934-6211118-49).

\section{Supplementary Materials}

Table S1: medicinal plant extracts evaluated in this study. (Supplementary Materials)

\section{References}

[1] World Health Organization, Global TB Report 2019, World Health Organization, Geneva, Switzerland, 2019.

[2] G. Brigden, C. Hewison, and F. Varaine, "New developments in the treatment of drug-resistant tuberculosis: clinical utility of bedaquiline and delamanid," Infection and Drug Resistance, vol. 8, pp. 367-378, 2015.

[3] S. J. Keam, "Pretomanid: first approval," Drugs, vol. 79, no. 16, pp. 1797-1803, 2019.

[4] M. Fujiwara, M. Kawasaki, N. Hariguchi, Y. Liu, and M. Matsumoto, "Mechanisms of resistance to delamanid, a drug for Mycobacterium tuberculosis," Tuberculosis, vol. 108, pp. 186-194, 2018.

[5] T. V. A. Nguyen, R. M. Anthony, A.-L. Bañuls, T. V. A. Nguyen, D. H. Vu, and J.-W. C. Alffenaar, "Bedaquiline resistance: its emergence, mechanism, and prevention," Clinical Infectious Diseases, vol. 66, no. 10, pp. 1625-1630, 2017.

[6] A. L. Harvey, R. Edrada-ebel, and R. J. Quinn, "The reemergence of natural products for drug discovery in the genomics era," Nature Reviews Drug Discovery, vol. 14, no. 2, pp. 111-129, 2015.

[7] D. Quan, G. Nagalingam, R. Payne, and J. A. Triccas, "New tuberculosis drug leads from naturally occurring compounds," International Journal of Infectious Diseases, vol. 56, pp. 212-220, 2017.

[8] D. J. Payne, M. N. Gwynn, D. J. Holmes, and D. L. Pompliano, "Drugs for bad bugs: confronting the challenges of antibacterial discovery," Nature Reviews Drug Discovery, vol. 6, no. 1, pp. 29-40, 2007.

[9] M. A. Jyoti, K.-W. Nam, W. S. Jang et al., "activity of methanolic plant extract of Artemisia capillaris containing ursolic acid and hydroquinone against Mycobacterium tuberculosis," Journal of Infection and Chemotherapy, vol. 22, no. 4, pp. 200-208, 2016.

[10] V. K. Gupta, A. Kaushik, D. S. Chauhan, R. K. Ahirwar, S. Sharma, and D. Bisht, "Anti-mycobacterial activity of some medicinal plants used traditionally by tribes from Madhya Pradesh, India for treating tuberculosis related symptoms," Journal of Ethnopharmacology, vol. 227, pp. 113-120, 2018.

[11] S. P. N. Mativandlela, J. J. M. Meyer, A. A. Hussein, P. J. Houghton, C. J. Hamilton, and N. Lall, "Activity againstMycobacterium smegmatis and $M$. tuberculosis by extract of South African medicinal plants," Phytotherapy Research, vol. 22, no. 6, pp. 841-845, 2008.

[12] A. Jimenez-Arellanes, M. Meckes, R. Ramirez, J. Torres, and J. Luna-Herrera, "Activity against multidrug-resistant $M y$ cobacterium tuberculosis in Mexican plants used to treat respiratory diseases," Phytotherapy Research, vol. 17, no. 8, pp. 903-908, 2003.
[13] P. Taylor, M. Arsenak, M. J. Abad et al., "Screening of Venezuelan medicinal plant extracts for cytostatic and cytotoxic activity against tumor cell lines," Phytotherapy Research, vol. 27, no. 4, pp. 530-539, 2013.

[14] S. Bardarov, M. S. Pavelka, V. Sambandamurthy et al., "Specialized transduction: an efficient method for generating marked and unmarked targeted gene disruptions in Mycobacterium tuberculosis, M. bovis BCG and M. smegmatis," Microbiology, vol. 148, no. 10, pp. 3007-3017, 2002.

[15] B. Boitel, M. Ortiz-Lombardía, R. Durán et al., "PknB kinase activity is regulated by phosphorylation in two Thr residues and dephosphorylation by PstP, the cognate phospho-Ser/Thr phosphatase, in Mycobacterium tuberculosis," Molecular Microbiology, vol. 49, no. 6, pp. 1493-1508, 2003.

[16] A. Villarino, A. Duran, P. Wehenkel et al., "Proteomic identification of M.tuberculosis protein kinase substrates: PknB recruits GarA, a FHA domain-containing protein, through activation loop-mediated interactions," Journal of Molecular Biology, vol. 350, no. 5, pp. 953-963, 2005.

[17] F. R. Pavan, D. N. Sato, C. T. Higuchi, A. C. B. Santos, W. Vilegas, and C. Q. E. Leite, "In vitro anti-Mycobacterium tuberculosis activity of some Brazilian "Cerrado" plants," Revista Brasileira de Farmacognosia, vol. 19, no. 1B, pp. 204-206, 2009.

[18] F. Gamboa, C.-C. Muñoz, G. Numpaque, L. G. SequedaCastañeda, S. J. Gutierrez, and N. Tellez, "Antimicrobial activity ofPiper marginatumJacq andIlex guayusaLoes on microorganisms associated with periodontal disease," International Journal of Microbiology, vol. 2018, Article ID 4147383, 9 pages, 2018.

[19] Y. Sánchez, T. M. Correa, Y. Abreu, B. Martínez, Y. Duarte, and O. Pino, "Caracterización Química y Actividad Antimicrobiana del Aceite Esencial de Piper marginatum Jacq," Rev. Protección Veg.vol. 26, no. 3, pp. 170-176, 2011.

[20] J. M. Alcântara, J. M. V. M. De Lucena, R. Facanali, M. O. M. Marques, and M. Da Paz Lima, "Chemical composition and bactericidal activity of the essential oils of four species of annonaceae growing in Brazilian Amazon," Natural Product Communications, vol. 12, no. 4, 2017.

[21] R. S. C. Cabral, C. C. F. Alves, H. R. F. Batista et al., "Composition of essential oils from different parts of Protium heptaphyllum (Aubl.) Marchand and their in vitro antibacterial activity," Natural Product Research, vol. 0, no. 0, pp. 1-6, 2018.

[22] A. Cáceres, B. López, X. Juárez, J. del Aguila, and S. García, "Plants used in Guatemala for the treatment of dermatophytic infections. 2. evaluation of antifungal activity of seven American plants," Journal of Ethnopharmacology, vol. 40, no. 3, pp. 207-213, 1993.

[23] M. Martínez-Vázquez, A. R. González-Esquinca, L. Cazares Luna, M. N. Moreno Gutiérrez, and A. N. García-Argáez, "Antimicrobial activity of Byrsonima crassifolia (L.) H.B.K," J. Ethnopharmacol.vol. 66, no. 1, pp. 79-82, 1999.

[24] J. L. Mendes, T. F. de Araújo, M. Geraldo De Carvalho, F. E. Aragão Catunda Júnior, and R. Albuquerque Costa, "Chemical composition and mechanism of vibriocidal action of essential oil from resin of Protium heptaphyllum," The Scientific World Journal, vol. 2019, Article ID 9563213, 6 pages, 2019.

[25] K. O. Ndjoubi, R. Sharma, and A. A. Hussein, "The potential of natural diterpenes against tuberculosis: an updated review," Current Pharmaceutical Design, vol. 26, no. 24, pp. 29092932, 2020. 
[26] F. H. Fernandes, Z. d. R. Guterres, I. M. P. Violante, T. F. S. Lopes, W. S. Garcez, and F. R. Garcez, "Evaluation of mutagenic and antimicrobial properties of brown propolis essential oil from the Brazilian Cerrado biome," Toxicology Reports, vol. 2, pp. 1482-1488, 2015.

[27] R. Capdeville, E. Buchdunger, J. Zimmermann, and A. Matter, "Glivec (STI571, imatinib), a rationally developed, targeted anticancer drug," Nature Reviews Drug Discovery, vol. 1, no. 7, pp. 493-502, 2002.

[28] P. Fernandez, B. Saint-Joanis, N. Barilone et al., "Ser/Thr protein kinase $\mathrm{PknB}$ is essential for sustaining mycobacterial growth," Journal of Bacteriology, vol. 188, no. 22, pp. 7778-7784, 2006. 